\title{
The Soul and the Virtues in Proclus' Commentary on the Republic of Plato
}

D. Gregory Maclsaac

\section{Q OpenEdition}

1 Journals

\section{Electronic version}

URL: https://journals.openedition.org/philosant/2645

DOI: 10.4000/philosant.2645

ISSN: 2648-2789

\section{Publisher}

Éditions Vrin

\section{Printed version}

Date of publication: 13 November 2009

Number of pages: 115-143

ISBN: 978-2-7574-0124-8

ISSN: 1634-4561

\section{Electronic reference}

D. Gregory Maclsaac, "The Soul and the Virtues in Proclus' Commentary on the Republic of Plato", Philosophie antique [Online], 9 | 2009, Online since 25 July 2019, connection on 02 December 2022 URL: http://journals.openedition.org/philosant/2645 ; DOI: https://doi.org/10.4000/philosant.2645

\section{(c) (i) (9)}

Creative Commons - Attribution-NonCommercial-NoDerivatives 4.0 International - CC BY-NC-ND 4.0 https://creativecommons.org/licenses/by-nc-nd/4.0/ 


\section{THE SOUL AND THE VIRTUES IN PROCLUS'}

COMMENTARY ON THE REPUBLIC OF PLATO

D. Gregory MacIsaac

Carleton University, Ottawa

RÉSUMÉ. Dans la septième dissertation de son Commentaire sur la République de Platon, Proclus fournit les éléments d'une philosophie politique néoplatonicienne très structurée. Fidèle, de façon générale, à la description platonicienne de l'âme tripartite et des quatre vertus cardinales, il introduit cependant d'importantes nuances dans cette théorie. L'idée de la prédominance d'une partie de l'âme sur une autre et l'idée de "vies mixtes » où deux parties de l'âme prédominent en même temps élargissent la description platonicienne des différents types politiques. En outre, en s'efforçant de donner diverses explications métaphysiques de la nature et du nombre des parties de l'âme et des vertus, Proclus inscrit la philosophie politique platonicienne plus ou moins tout d'une pièce dans une hiérarchie cosmique néoplatonicienne.

SUMMARY. In the 7th essay of his Commentary on the Republic of Plato, Proclus supplies the elements of a fairly robust Neoplatonic political philosophy. In general he agrees with Plato's account of the tripartite soul and the four cardinal virtues, while introducing important nuances into the theory. The idea of the dominance of one part of the soul over another, and the idea of 'mixed lives', where two parts dominate at once, extend Plato's account of the various political types. Further, in his attempt to give various metaphysical explanations for the nature and number of the parts of the soul and the virtues, Proclus inserts Platonic political philosophy more or less whole-cloth into a Neoplatonic cosmic hierarchy. 

Proclus the Platonic successor was the happiest of men, or so his biographer Marinus would have us believe. From Plotinus on, Neoplatonic authors posited a hierarchy of virtue, conforming to their general idea of the analogous structure of reality. ${ }^{1}$ Marinus used this hierarchy to structure his Life of Proclus, claiming that Proclus was wise, courageous, temperate, and just in every way, and so possessed the completion of natural, moral, political, purifying, contemplative, and theurgic virtue. ${ }^{2}$ So Proclus was happiest (eudaimonestaton), because more than any other man he possessed the whole of virtue. ${ }^{3}$

With his recent book Platonopolis, Dominic O'Meara has corrected our assumption that the Neoplatonists did not have much to say about political philosophy. ${ }^{4}$ In this paper I will examine an aspect of Neoplatonic political philosophy which concerns political virtue, by looking at the seventh essay of Proclus' Commentary on the Republic of Plato. ${ }^{5}$ The fact that there are very few studies of this commentary, ${ }^{6}$ and that it is the last major work of Proclus without an English translation either complete or

1. Some of the important texts are Plotinus, Enn. I.2; Porphyry, Sent.32; Marinus, Proclus; Damascius, In Phaed. I, \138-144; Olympiodorus, In Phaed. 1, \4.9-5.9. See also Proclus, In Remp. I.12.25-13.6; Proclus, In Alc. 96.7-16. And see O’Meara 2003, p.40-49; Saffrey \& Segonds 2001, introduction, p. lxix-c; Brisson 2004; Baltzly 2004; Baltzly 2006. Also useful is Festugière 1969.

2. Physike, ethike, politike, kathartike, theoretike, and theourgike arete. This scheme varies from author to author. Marinus is not able to posit all four virtues equally at every level, and gives up the scheme entirely when it comes to the theurgic virtues. See the introduction of Saffrey \& Segonds 2001, cited in note 1.

3. Marinus, Proclus, $\$ 2.5$.

4. O’Meara 2003.

5. In Remp. I.206.1-235.21.

6. The list is quite short. For example, there seem to be only four book-length studies, and all of them deal with some aspect of Proclus' attitude towards poetry. See Sheppard 1980; Cardullo 1985; Kuisma 1996; Pichler 2006. There are a few shorter studies of political aspects of the In Rempublicam: Abbate 1999; Abbate 2006; Longo 2002; Narbonne 2004; Perkams 2006; Stalley 1995; Stalley 1999. For a study of the lower parts of soul which draws specifically on this essay in the In Rempublicam, see Opsomer 2006.

Philosophie antique, $\mathrm{n}^{\circ} 9$ (2009), 115-143 
under way, ${ }^{7}$ underlines O'Meara's point that we did not notice Neoplatonic political philosophy mainly because we did not expect to find any, ${ }^{8}$ and so were not looking for it. ${ }^{9}$ In this context, Proclus' short essay ( $30 \mathrm{pp}$. in Kroll's edition) on the parts of the soul and the political virtues is a good example of an important text which has previously been overlooked. What we find in this essay, moreover, is Proclus' very ambitious attempt to situate the level of political virtue within his overall system, by giving a metaphysical account of the number and nature of the four virtues and the three parts of the soul from Plato's Republic.

\section{I}

In this essay Proclus is not content simply to explain what the political virtues are. Rather, he wants to explain why there are political virtues at all, and why they are these four. Because this requires a discussion of the parts of the soul and their mutual relation, it is the parts of the soul which occupy most of the essay.

Proclus begins by stating, in effect, that the political virtues come into being because of the soul's relation to its body. He states that the perfection (teleiotes) and activity (energeia) of something differs depending on whether we consider it in itself, or in relation to something else. ${ }^{10}$ So just as "man" (anthropos) and "master" (despotes) are not the same thing, even though a master is also a man, the perfections of man and master will not be the same. Likewise, it is not the same thing to consider the soul in itself (baplos) and the soul as ruler of the body (somatos archousan). ${ }^{11}$

7. There is, of course, Festugière 1970, and Abbate 2004 (a partial Italian translation). The Platonic Theology is in no modern English translation, but it does exist in the English of Thomas Taylor. The Elements of Physics has also not been translated into English, but is not usually considered a major work.

8. See Dillon 2001, p. 243: "Both dialogues [the Republic and the Laws] contain a great deal of political theory, and this was not a topic of great concern to Platonists of this period." Dillon does admit, however, some interest among Neoplatonists in political theory (p. 244), and at the beginning of his article he lists the few passages in Middle and Neoplatonism which engage with the political content of the Laws.

9. O’Meara 2003, p. 4: “A consequence of the conventional view... is that no systematic study of Neoplatonic political philosophy has been attempted." O’Meara's longstanding interest in Neoplatonic political philosophy seems to be the exception rather than the rule. Aside from Platonopolis, see for example O’Meara 1992, p. 508ff.; O’Meara 1999; O'Meara 2002. For a partial consideration of Neoplatonic ethical and political thought in relation to Plato himself, see Gerson 2004. For a consideration of the same in relation to Medieval thought, see Hankey 2003; Cheneval 1996.

10. Just as the existence (byparxis) of something is different from its relation to another thing (pros allo schesis). In Remp I.207.16-20.

11. In Remp. I.207.20-23. 
It is the soul as ruler of the body which gives rise to political virtue, and it is precisely the relation of ruling or being ruled which interests Proclus. ${ }^{12}$ Each of the three parts of the soul has an activity or work considered before any relation, which issues by nature from its essence. ${ }^{13}$ The rational part (logos) accomplishes its own work when it lives a purified (kathartikos) and contemplative (theoretikos) life; ${ }^{14}$ spirit (thymos) does its own work when it takes vengeance, rendering pain for pain; and the nature of appetite (epithymia) is an insatiable desire for all pleasures. ${ }^{15} \mathrm{But}$ because in the soul which rules the body these parts are not found in isolation, but instead are joined together and live a single life (mian zoen), there comes into being political virtue and vice. And so Proclus defines political virtue as "a habit which perfects the parts of the soul in their mutual relation" and vice as "a habit which destroys the vital relation which these parts naturally have towards each other." 16

The mutual relation which these parts have is one of ruling and being ruled. ${ }^{17}$ So the study of the political virtues turns into an investigation of the parts of the soul, their number and nature, in order to specify which should rule or be ruled. This is why Proclus' essay only briefly discusses virtue and vice, spending most of its time on an examination of the parts of the soul as the underlying question.

Proclus thinks that the same reasoning holds for the classes in Socrates' city in speech. They also have a double ergon: the Guardian considered by himself will seek to rise to the Good through contemplation; the Auxiliary will exercise his force indiscriminately, making war when and with whom he pleases; and the 'money-maker' (chrematistes) will buy and sell, seeking only to increase his fortune. But because they exist together within the city, their virtues and vices consist in their mutual

12. He adds the term autopragia, independent action, to teleiotes and energeia, as something which changes with the relation of ruling or being ruled. The verb for ruling is archein. In Remp. I.207.30-208.2.

13. Such an activity is natural, or belongs to the part considered in itself. In Remp.

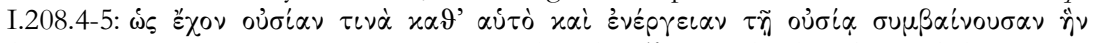

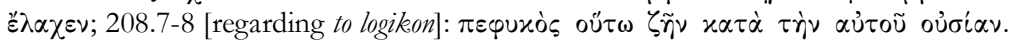

14. Note that these terms designate the two levels in the hierarchy of virtue which come after the political.

15. In Remp. I.208.5-22.

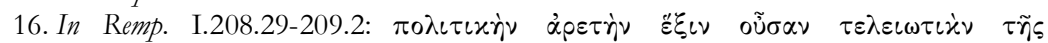

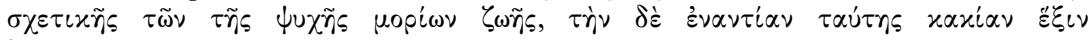

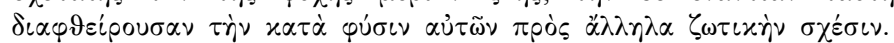

17. At In Remp. I.208.19, Proclus refers to Resp. 341d7, where Socrates states that every ruling art provides the good for its subjects. See Proclus' specification of the various sorts of rule at In Remp. I.228.20-27. 
relation of ruling and being ruled. ${ }^{18}$ According to Proclus, the virtues in the soul preexist (prohyparchein) as models (paradeigmata) of the virtues and vices in the political classes in Socrates' city. When they work inside the soul, the political virtues order the soul, and when they proceed (proiousai) outwards, they order the city.

All forms of rule (hai archai) are relations, both the psychic and the political, but those which are exterior are imitations (mimeseis) of the interior ones and are secondary activities [issuing] from those which act primarily (protourgon). And the true political art is about the interior activities, because it brings order to the parts which are ruling and ruled in the primary sense, just as the political art which considers the political classes to be images [of the parts of the soul] is [itself] an image (eikon) of the true political art. Or rather, the political art is one habit (bexis) which has a double activity, one which concerns the parts which rule and are ruled inside the soul, and the other which orders external things. ${ }^{19}$

So for Proclus the study of political virtue is really the study of the soul.

\section{II}

Proclus thinks that this is exactly what Socrates does in the Republic. He begins with a determination of the political classes, and from this is

18. In Remp.I.209.6-210.5. One might think that Proclus' account here of a double activity is similar to Plotinus' account of the internal and external activity of the hypostases of Nous and Soul, explained through such metaphors as that of heat and fire, where the heat in the fire is the internal activity and the heat which radiates is the external activity (Enn. V.1.3). But there are important differences between this theory and what Proclus is saying here. First, the external activity in Plotinus becomes hypostasised as an independent reality. That is to say, Soul can be thought of in a way as the external activity of Nous. Second, and because of this first point, there is always a hierachical relation between the internal and external activities in Plotinus, with the external subordinate to the internal. Neither of these is the case with Proclus' account here of the same thing having one energeia in itself and another in relation to something else. The energeia of master, for example, is ruling. If this were the same as Plotinus' theory, the energeia of master would be the slave itself. Further, for the lower parts of the soul, the energeia in itself is 'lower' than the energeia in relation to another, insofar as it is their relation to logos which brings them into a better condition than they would have been otherwise. So although at various points both Proclus and Plotinus speak of a double activity, their discussions are about different things.

19. In Remp. I.210.25-211.3. I fail to see the need for Kroll's conjecture here, which

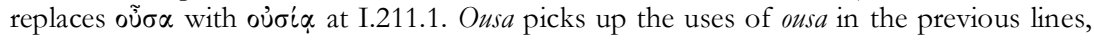
and is parallel with echousa in the next phrase, so that the contrast is not between being a single habit in essence, with a double activity. Rather, it is a contrast between being a single habit, and having a double activity. See also In Remp. I.217.11, where the virtues of the whole city are called eikones of those in the individual soul. 
able to determine the virtues appropriate to each. On the basis of this, Socrates is then able to determine the parts of the soul itself and its virtues. ${ }^{20}$ Proclus claims that this is the proper order to proceed because, "you cannot know any of the interior habits (bexeis) of the soul and the activities which remain (menousas) inside it in any other manner than by beginning from the activities which proceed (prö̈ouson) outwards."21 Proclus might mean that an empirical study of men's actions in the city is necessary in order to draw universal conclusions about the content of

20. In Remp. I.217.6-228.27. Abbate 2006 discusses Proclus' account of Justice and Temperance, in this 7th essay. Abbate's thesis is that it is through these virtues that Proclus thinks the Soul is one, and imitates analogically the One as the Principle of all things. I think this is correct, but I would emphasise that in saying that Justice and Temperance impart a harmony to the Soul which makes it one, this does not mean that its multiplicity is lost. In fact, it is important to keep in mind that the manner in which the Soul is many is also its manner of being one. The soul's harmony is its unity, because what for the One is unspeakable simplicity, on the psychic level is the harmony of various parts. Harmony holds the analogical place of unity here. My point is that we shouldn't think that harmony is one thing and the unity which it brings about is another. The unity of a body is its organic coherence, the unity of a table is the physical attachment of its parts, the unity of a city is the harmony of its citizens, and the unity of the Soul is the harmony of its various parts.

At the end of his essay, Abbate makes the point that politics in Proclus is not possible without a metaphysical-theological foundation. He states, "The city of men must assimilate itself, as far as possible, into the perfect harmony of the cosmos, which depends on the providential care of the Demiurge. In conclusion, this means that politics has to assimilate itself into metaphysics and theology. In Proclus, political theorization actually takes the shape of a metaphysical-theological politics. Consequently, the philosopher is not conceived as a true ruler, but as an imitator of the demiurgic action which assures the good and the prosperity of the 'Whole' as an organic and harmonious unity" (p. 198). I think Abbate is fundamentally correct here, with the caveat that it is not clear what he means by saying that the philosopher is not a true ruler. As Abbate points out, the Demiurge is called by Proclus at various points the highest 'politician' of the cosmos, in that he brings its various parts into harmonious order. And Proclus thinks that Plato's true Guardian, the philosopher, plays an analogous role for the city. But why say that the philosopher is not a true ruler? The metaphysical principle of analogy is what makes the harmony in the city an image of, and indeed a lower manifestation of, the harmony of the parts of the cosmos. And this truth can only be understood through the sort of theoretical metaphysics which Proclus is doing. The Procline Philosopher King must possess this metaphysical knowledge in order to know what to aim at in his legislation. But in reforming the city in accordance with divine models, when turning from the order of the cosmos to the ordering of the Cave, it would seem that he is in fact a true ruler. My point is that Proclus' political philosophy, as Abbate demonstrates clearly, is completely dependent on his metaphysics. But the practical activity of ruling - political action as opposed to political theory - cannot itself be metaphysical speculation. Rather, it is the practical bringing about of the harmony of the various classes in the city through concrete legislation. And Abbate seems to think this too, hence it is not clear to me what he means by saying the philosopher is not a true ruler.

21. In Remp. I.210.17-20. 
the soul. And he does mean this, in a sense. But Proclus is obviously not an empiricist, so any investigation of political action must serve to remind the soul about its own innate ideas. His general theory of discursive reason (dianoia) states that we know the logoi which remain in the soul's essence (ousia) through the activities which proceed from this essence, which he calls projections (probolai). ${ }^{22}$ That this is an ontological as well as an epistemological doctrine is illustrated nicely here. In the same way as we know the soul's ousia through the processions which are our thoughts, Proclus clearly thinks that we can come to recollect the structure of the soul through the activities (energeiai) which proceed from it, the actions of men in the city.

That this is really a theoretical, not an empirical, investigation is shown by Socrates' procedure in the Republic, because Socrates determines the classes in the ideal city according to necessity. Proclus points out that Socrates introduces the classes in a certain order (en taxee), because he begins with "men who spend their time on only the necessities of life (ta anankaia), without experience of war or education, living according to nature (kata physin). ${ }^{23}$ Necessity leads him to introduce a soldier class, because of external enemies. And finally, because there must be (dein) an education for the soldier class, the philosophers are needed. ${ }^{24}$ This is not an investigation of how things are in various cities so much as how they must be in the well-ordered city.

Proclus' account of the virtues in the city is as one would expect, with one interesting addition. He thinks that it is their excellence in mousike which has disposed the rulers of the city towards wisdom, because it has taught them about goods and evils. So the city is wise because of its rulers, courageous through the soldiers, temperate especially because of the money-makers, and their mutual agreement about who rules and who is ruled, each class carrying out its own proper role, makes the city just. ${ }^{25}$

Before showing how Socrates distinguishes the parts of the soul, Proclus claims that the ways of life which characterise different peoples have their source in the domination of their souls by one or another part. So the Greeks are inclined to phronesis, the Thracians are more thymotic, and the Phoenicians are inclined to money-making. In the first logos dominates, and in the other two thymos and epithymia, respectively. ${ }^{26}$ Proclus probably included this discussion in order to illustrate the point which he

\author{
22. See MacIsaac 2001. \\ 23. In Remp.I. 217.19-20. \\ 24. In Remp. I.218.18-19. \\ 25. In Remp. I.219.17-220.8. \\ 26. In Remp. I.221.20-24.
}


made earlier, that the exterior activities of the soul, political actions, issue from and are images of the soul's interior activities.

Proclus' explanation of how Socrates distinguishes the three parts of the soul is, again, what one would expect. ${ }^{27}$ The inability to undergo

27. Perkams 2006 argues that Proclus' account of the parts of the soul differs greatly from that of his predecessors. He says that earlier Neoplatonic thinkers hold that the soul is substantially one, and that its parts are different powers, and so that it is polydynamos. Proclus, according to Perkams, thinks instead that the parts of the soul are different substances (ousial). Perkams' evidence for this is drawn largely from this 7th essay in Proclus' Republic commentary. Perkams thinks that this is a bold innovation on Proclus' part, intended to explain how the soul can have both rational and irrational functions: "on the one hand, the transcendent rational soul cannot be the same substance than [sic] the nonrational, which is not separable from a perishable body" (p. 179). The soul is still a unity, however, because the lower substances are irradiations of the higher, and have a sort of hylomorphic relation, according to which the higher substance informs the lower as matter (p. 177, 179). The soul unfolds itself into different substances simply as a part of the self-diversifying unfolding of the cosmos as a whole (p. 181). While I agree with Perkams' account of how the soul is one, because in Proclus things are both one and many through their self-unfolding, I think his main thesis that in Proclus there are many substances in the soul is misleading. It is one thing to say that logos, thymos, and epithymia differ kat'ousian, as Proclus does, and as Perkams points out (In Remp. I.207.9-10, I.224.18ff.). But this is not the same thing as saying that they are different substances, in the manner in which Perkams seems to understand this. He says that Proclus' soul "is a compound of several beings or substances, each different from the others" (p. 167). He interprets Proclus' statement of difference kat'ousian to mean that "Proclus introduces within the soul the broadest ontological difference allowed by the Aristotelian terminology: Plato's three parts of the soul are much more different from each other than simple faculties, they are even more different than the parts of one substance - each of them is a single entity with a proper definition and a proper way of perfection" (p. 172. See also, 176, 177, 182). This way of speaking is too Aristotelian to capture what Proclus means. The fact alone that Proclus thinks the ousia of the soul is self-diversifying, and that parts of it can serve as quasi-formal principles for other parts as quasi-material principles, shows how far Proclus' understanding of ousia is from Aristotle's. To say that two things differ kat'ousian in Proclus is not primarily to say that they are separately existing subjects, separate 'thises'. Rather, it is to say that they differ in their being, in what they are, and that they are not simply two powers or operations of something which is single in being. This mode of speaking can apply to different parts of a single ousia. How else could the parts of a single ousia differ from one another than kat'ousian? They certainly will not differ only kata dynamin or kat'energeian. Proclus' account of the soul in the Timaeus commentary indicates an extremely complicated structure, in which its ousia is divided into many different parts but is still one (In Tim. II.47ff., II.147.19-257.29. See esp. II.257.10-29). And in this 7th essay, Proclus distinguishes between memory and sensation, saying that their existence (byparxis) is distinct from each other in relation to a single ousia, an ousia, however, which possesses an essential multiplicity (plethos ousiodes) (In Remp. I.233.18-23). In the line previous, he says that the Form of this nature (touto tes phuseos to eidos) is both one and many, probably referring to the soul's ousia as both one and many. In the Euclid commentary, Proclus says that the soul contains the straight and the circular kat'ousian, referring to the Timaens, because this allows it to be allied to the intelligibles (circle) and preside over the sensibles (straight) (In Eucl. 1087.10-109.4). In other words, it exercises 
contraries at the same time and in the same respect shows that logos, thymos, and epithymia are distinct. ${ }^{28}$ However, his description of the soul's virtues is interesting. If Socrates had wanted to use language which was familiar to the many, "he would have said that phronesis is the virtue of logos, courage is the virtue of thymos, justice the virtue of the moneyloving part of epithymia, and temperance of the other part of epithymia, the pleasure-loving part." ${ }^{, 9}$ Instead, Proclus says, he wanted to show how the virtues in the soul are analogically related to the political classes, and therefore defines them in terms of which parts of the soul rule, and which are ruled.

So Proclus finds in Socrates' procedure in the Republic an investigation which begins from the external activities of the soul and returns inwards, from the images in the political sphere to the paradigms in the soul. In the city and in the soul animating a body there are three parts, and political virtue in each case has to do with the mutual relation of ruling and being ruled.

\section{III}

So far I have presented the parts of Proclus' account which stay fairly close to the Republic. In two ways, however, Proclus goes far beyond Plato in this essay. The first way is by raising and answering questions

rational and irrational functions in virtue of the complexity of its ousia, not in virtue of having more than one ousia. I don't see much difference between the circular and straight, in that context, and between logos on the one hand, and thymos and epithymia on the other, here. The passage which might be thought to support Perkam's language most strongly is also what decides against it, at In Remp. I.226: "Therefore the appetitive part is essentially (kat'ousian) one and many, and because of this it also has powers (dynameis) which fight [against each other], because they issue from different substances (apo ousion diapherouson hormemenas)." Proclus is arguing here that the appetitive part is not more than one part, and that the division into logos, thymos, and epithymia doesn't have to be complicated by further subdividing epithymia in two. Rather, the multiplicity of epithymia is because of its relation to the body. But if Proclus can say with regard to epithymia even that it has different ousiai, but that it is one and many kat'ousian, clearly meaning not that it is many things but that it is one ousia which is internally complex, it is likely that this is his account of the ousia of the soul as a whole. So this overly Aristotelian language of distinct substances gives a mistaken impression of what is going on here. Rather, a Procline ousia is just the sort of thing which is one and many at the same time, and each of its parts differs kat'ousian from each other. It is likely that Proclus' distinction from his predecessors, who according to Perkams called logos, thymos, and epithymia mere dynameis of the soul, has its source in the implausibility of a simple ousia without parts carrying out radically different and opposed activities. So while Perkams is generally accurate in his account of the internal complexity of the Procline soul, and is correct to notice Proclus' bold theory of the self-diversification of the soul's ousia, his overly Aristotelian description obscures how bold it is, how the soul's ousia in Proclus really is both one and many at the same time.

28. In Remp. I.223.1-224.19.

29. In Remp. I.228.4-7. See below for the division of epitbymia into two parts. 
which Plato does not deal with. The main examples of this are: (1) If both logos and thymos rule within the soul, why do they have distinct virtues? $?^{30}$ (2) If epithymia desires contraries, how can it still be a single part of the soul? ? $^{31}$ (3) Why are there only three parts of the soul? ${ }^{32}$ (4) How are aisthesis and phantasia related to the three parts enumerated in the Republic, and why do they not serve to increase the number of parts beyond three? $?^{33}$ (5) Why is the soul still one, if it has three parts? $?^{34}$

The second way in which Proclus goes beyond Plato follows from the first. Proclus naturally solves the questions which arise in Plato's text by explaining what he thinks is the truth about the cosmos. In so doing, he fits what he finds in the Republic into his own system, and does so as usual while attributing his own doctrines to Plato. We will see that Proclus' attempt here is not entirely successful, and by invoking different aspects of his system at different points, he ends up making a few assertions that are difficult to reconcile with each other. In the end, I think we have to read his treatment as a series of (hopefully) complementary analyses of that unified thing which is the soul.

We must admit, as well, that Proclus' treatment of his subject here does not make it easy to see in a clear and orderly manner what he is up to. The great difficulty in coming to know Proclus' philosophy well is less a function of its complexity, than of the manner in which he presents it. The majority of his works are commentaries on Plato, each consisting of a series of discussions which arise from the various lemmata from the Platonic text. In effect, Proclus usually presents his system, which is many times more complex than Plato's philosophy, by closely following not its own internal movement, but the order of topics which he finds in various dialogues. Consequently, while his works usually have some sort of overall plan, they often do not give a very orderly and clear presentation of their subject matter. The Elements of Theology is the great exception, with the Platonic Theology and the commentary on Euclid being more orderly than most. The Republic commentary is an interesting case. It is not a continuous commentary, but in fact only a series of essays on various parts of the Republic, varying greatly in length. Within this 7th Essay, Proclus does not comment on lemmata, but rather under the general rubric of an examination of the parts of the soul and its virtues, in itself

30. In Remp. I.214.8ff. I will not discuss this in detail. The quick answer is that they rule in different ways. Logos rules by making correct judgements, while thymos rules by exerting force against epitbymia. See In Remp. I.214.8-215.27.

31. In Remp. I.225.4ff.

32. In Remp. I.229.1ff.

33. In Remp. I.232.15ff.

34. In Remp. I.234.1ff. 
and in relation to the city, he presents a series of discussions which are sometimes only loosely related to each other. ${ }^{35}$ Festugière divides the essay in three, providing the headings: A) Consideration of the subject in itself; B) How Socrates has treated the subject; and C) Corrolaries. In what follows I will be moving back and forth between the various parts, and at times emphasising discussions which in the text are very brief, 36 in order to show more systematically than is immediately apparent from the text what Proclus is up to. ${ }^{37}$

\section{IV}

Because the investigation of the political virtues is really an investigation of the parts of the Soul, Proclus supplies various explanations of why there are three, and only three, parts in the soul which rules the body, and the relations between the parts. What follows are the four main explanations of this question.

(1) Ruling and being ruled: Proclus' main account, as I have stated above, is the relation of ruling and being ruled. Logos rules because it is naturally related to nous, and epithymia is ruled because it naturally concerns the body. Thymos both rules and is ruled. It is ruled because, like epithymia, it needs to be directed by logos. But it also rules, because it as-

35. For example, in the middle of his discussion of which parts of the soul rule and which are ruled, and how these relations generated the need for the four virtues, he presents an entire page on the Pythagorean doctrine of the fourth, the fifth, and the octave as a comment on Plato's remark that temperance is a sort of "consonance and harmony" (430e). See In Remp. I.212.25-213.28.

36. For example, his treatment of hyparxis, dynamis, nous (In Remp. I.226.15-23), and his discussion of the three-quality theory of body and soul (In Remp. I.229.9-230.5).

37. Proclus treats the subject as a whole in the following order, giving a number of minor points long digressions, citing a number of important metaphysical principles only in passing, and treating the same or similar subjects more than once. These are the main topics: (1) That the consideration of the parts of the soul and the political classes differs if they are taken in themselves or in relation to each other (I.207.14ff.); (2) That the virtues are four in number, in the soul and in the city, with an explanation of the relations of ruling and being ruled (I.211.4ff.); (3) Socrates' determination of the three classes and the virtues corresponding to each class (I.217.6ff.); (4) The diversity of virtues in different nations (I.221.12ff.); (5) That the three parts of the soul are not the same as each other, including a discussion of why epithymia is only one part, and how the triad hyparxis, dynamis, nous shows that the soul has three parts (I.223.1ff.); (6) Another discussion of the four virtues in the soul (I.227.27ff.); (7) Why there are only three parts in the soul, including a discussion of the three-quality theory of body and soul, and intermediate forms of life making use of more than one part (I.228.28ff.); (8) A discussion of aisthesis and phantasia (I.232.15ff.); (9) How the soul is one, although three (I.233.29ff.); (9) Presentation of an overall schema by which the irrational powers are images of the parts of the rational soul (I.235.1ff.). 
sists logos when epithymia fights against it. ${ }^{38}$ We can see here Proclus' principle of mean terms, so that in between that which desires nous and rules, and that which desires the body and is ruled, is something which both rules and is ruled, and which does not desire the body but which also is not rational. ${ }^{39}$ This idea of thymos as intermediary will be seen in a different manner below, in the three-quality theory of the soul and body.

These relations of ruling and being ruled give rise to the virtues. Logos has phronesis as its virtue, according to which it determines standards of action for itself and the other parts. Epithymia has temperance, according to which it regulates its desires, turning itself (epistrephomene) towards logos. The virtue of thymos is courage, as ruling, according to which it keeps epithymia down, and temperance, because it also accepts its rules from logos. Justice is the virtue of all three parts, insofar as they retain their proper role as ruling, being ruled, or both ruling and being ruled. ${ }^{40}$

At the beginning of this essay, Proclus specifies that he is examining the "soul as ruler of the body (psychen somatos archousan)." of the parts of the soul clarifies what he means by that phrase. On the one hand, the soul rules the body itself, because without the soul the body would just be a dead thing. But according to Proclus in this essay the body itself has no appetites. ${ }^{42}$ All bodily desires come from epithymia. So the soul rules the body, in the most accurate sense, by ruling itself, when logos lays down rules for epithymia, and thymos helps enforce those rules.

(2) The three-quality theory of body and soul: Proclus puts forward a threequality theory of body and soul in order to explain why there are three, and only three parts of the soul ruling the body. This theory is modelled after his three-quality theory of the elements in his Commentary on the Timaens, where it is stated more elaborately and in more mathematical terms. ${ }^{43}$ He states it briefly here by saying that for any two objects which have three opposed properties there exist two mean terms. Each mean

38. In Remp. I.211.4-26.

39. This principle is stated in El. Th. prop. 28, "Every producing cause brings into existence things like to itself before the unlike." This proposition has to do with causation, but it dictates that there are no gaps in the Procline universe, so that at no point in the unfolding can there be absolute difference between terms. Taken schematically, as Proclus does here, it means that between any two hierarchically ordered terms which are dissimilar you will find a term which is similar to the higher in one way and the lower in another.

40. In Remp. I.211.26-212.20; 213.28-214.7

41. In Remp. I.207.22-23.

42. We will examine this next, with the three-quality theory of body and soul.

43. In Tim. II.28.15-42.1, see esp. II.39.20-41.14. See also MacIsaac 2001. In the In Timaeum Proclus gives an elaborate explanation of this doctrine of mean terms, showing how it is true arithmetically and geometrically, and how it applies to the physical qualities of the four elements. Cf. El. Th. prop. 28, and note 39 above. 
term shares two properties with its closest extreme, and the mean terms themselves share two properties. In this way, the opposed extremes are joined by means. In the Timaeus commentary Proclus uses this theory to explain why between Fire and Earth we find Air and Water.

Each element is either Subtle or Dense; Penetrating or Obtuse; very Mobile or Immobile. The schema of the elements is as follows:

\begin{tabular}{llll} 
Fire: & Subtle & Penetrating & Mobile \\
\hline Air: & Subtle & Obtuse & Mobile \\
\hline Water: & Dense & Obtuse & Mobile \\
\hline Earth: & Dense & Obtuse & Immobile
\end{tabular}

So Air and Water, each sharing two of their three qualities with their neighbours, are mean terms between Fire and Earth. With regard to soul and body, Proclus says that the three qualities have to do with being (on), life (zoe), and intellect (nous), so that the operative qualities are partless (ameres) or having many parts (polymeres); having appetition (orektikon) or having no appetite (anorekton); being intelligent (noetikon) or not intelligent (anoeton).

\begin{tabular}{|l|l|l|l|}
\hline & on & zoe & nous \\
\hline Logos & partless & appetition & intelligent \\
\hline Thymos & partless & appetition & not intelligent \\
\hline Epitbymia & parts & appetition & not intelligent \\
\hline Body & parts & no appetite & not intelligent \\
\hline
\end{tabular}

So thymos and epithymia here are thought of as means between logos and body, and communicate with each of their neighbours by sharing two of their three qualities with them. ${ }^{45}$

We should notice a few things about this scheme. First, Proclus holds that all three parts of the soul have appetite, but the appetites of logos and thymos are for non-bodily things (the intelligibles and honour, respectively), while the appetite of epithymia is for the body and bodily things. ${ }^{46}$ Second, Proclus says that thymos is partless because it is "simple (haplous) in its own nature and because of this forms one class of citizens (mian... politeian)." 47 it is not clear if Proclus can assert the simplicity of thymos in this manner, and below we will see how thymos is also double. Epithymia has parts, Proclus says, "which is why it is called a beast with many heads (polykephalon legetai therion) and belongs to many classes of citizens (eis

44. In Remp. I.229.9-230.5. 2006.

45. For a very good analysis of the lower parts of the soul in Proclus, see Opsomer

46. In Remp. I.231.1-8.

47. In Remp. I.229.20-21. 
pleious syntelei politeias)." ${ }^{48}$ What Proclus means by this is probably that members of the soldier class are simply soldiers, while the money-makers are engaged in many different sorts of work in order to make money. Finally, notice that the only difference between thymos and epithymia is that one is partless and the other has parts. This seems to be a strange parsing of the Republic, but I think it makes sense. In effect, the distinction between these two parts of the soul is that one looks upward towards the partlessness of the immaterial and the other looks downward towards body. This will be confirmed by the third and fourth explanations of the soul's parts, which we will examine next.

3) Hyparxis, dynamis, nous: Proclus uses the triad of hyparxis, dynamis, nous to explain why epithymia is a friend of the body, but in so doing he supplies another explanation of why there are three parts of the soul. ${ }^{49}$ He states that the reflections (emphaseis) of the terms of the triad byparxis, dynamis, nous reach different levels of the soul. These varying reflections of the prior triad determine the object of the appetite which each part of the soul has. But they also obviously give a compelling reason as to why there are three parts, because we should expect the soul as an image of its principles to display their triadic structure.

The reflection of hyparxis reaches all the way to epithymia, and so epithymia loves the body. The connection between hyparxis and love of the body, according to Proclus, is that the body participates only in byparxis, not dynamis or nous.50 Thymos loves dynamis and logos desires nous, because the reflections of these two principles reach as far as these parts of the soul. Proclus invokes here his principle that "the reflections of the first [principles] reach through more things [than those of the secondary principles]... and the higher [principles] are objects of desire for more things

48. In Remp. I.229.24-25.

49. In Remp. I.226.15-23.

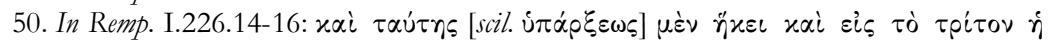

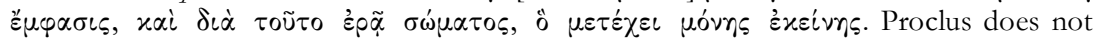
give an explanation here of why the body participates only in byparxis. However, his reasoning is likely as follows. The power of the higher cause extends further than the lower cause. In the triad hyparxis, dynamis, nous, the first term is hyparxis (existence) because of its greater simplicity than dynamis or nous. This greater simplicity of the higher cause has its mirror image in the greater simplicity of the lower effect. The body does not exhibit the complexity of dynamis, because it does not live, nor of nous because it does not think. Remember that hyparxis, dynamis, nous is parallel to on, zoe, nous and all other Procline triads. Therefore, its lack of complexity indicates that the causal power of these lower principles have been exhausted at this point, and all that is left for body to participate is hyparxis. Note as well that Proclus is using a triad to explain the structure of four terms, with body being the fourth term. See props. 56-58 of the Elements of Theology, where the power of the higher cause extends further than that of the lower. See Dodd's note on p. 232 of his edition, and Plat. Theol. III.6.21-26 Saffrey-Westerink, which Dodds refers to (as 127-9). 
than are the lower [principles]. So the lowest part of the soul is a lover of the body and desires only this, to save the body."

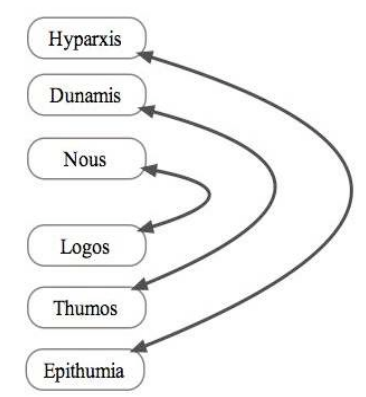

Before considering the fourth and final explanatory scheme, we need to discuss two related points. First, we should note that the second and third explanations for the parts of the soul, the three-quality theory and the soul as an image of byparxis, dynamis, nous allow us to understand why thymos is an ally of logos and not epithymia. Body has only byparxis and so epithymia as the final part, having only the emphasis of byparxis, can only desire body. Likewise with the three-quality theory, epithymia shares the quality with body of having many parts, and so its appetite is directed towards the body. Thymos, on the other hand, has the reflections of a higher principle, dynamis, so even though it is irrational it can aspire to more than body. Similarly, in the three-quality theory, the partlessness of thymos allows its desire to aim at the immaterial, which is likewise partless. Both of these taken together illumine Proclus' account of thymos within the schema of ruling and being ruled. Thymos must be ruled, because it is irrational, but because its desire tends towards something immaterial, towards honour rather than towards bodily things, it is the natural ally of logos and can assist it in ruling epithymia. The fourth explanation which Proclus gives, which we will examine below, confirms this interpretation, phrasing it in terms of the direction of the appetite: the appetite of thymos is directed upwards, while that of epithymia aims downwards.

Even though it is the natural ally of logos, however, thymos is more connatural (syngenesteron) with epithymia than with logos: "These two [thymos and epithymia] have the same father, while logos has a different father; these two are mortal and either exist or do not exist together, while logos is immortal; these two cannot receive knowledge, while logos by nature is cognitive (gnostikos)." 52 This suggests that the two lower parts of the soul come into existence with the body, and pass away at its death. However, 
Proclus' account of the soul's various bodies is rather complex. In short, thymos and epithymia belong to the soul's middle sort of body, the pneumatic vehicle, and survive as long as it survives. Therefore they survive the soul's various incarnations in a material body, but pass away with the pneumatic body at the end of the soul's total cycle of reincarnations. ${ }^{53}$

The second side-point concerns aisthesis and phantasia, which Proclus discusses near the end of his essay. These differ from the three parts of the soul already enumerated, and from each other. Aisthesis is described in interesting terms. It is different from logos because it is alogos; but it differs from the alogoi parts thymos and epithymia, because they are appetitive (orektikon) while it is cognitive (gnostikon). Moreoever, aisthesis underlies (bypokeitai) the other three parts, insofar as the recollections (anamneseis) of logos are di' aistheseos, and the movements of the other two are met' aistheseos. ${ }^{54}$ Phantasia, for its part, differs from aisthesis because it can conserve its impressions, and belonging to the memorative (mnemoneutikon) part of the soul it is closer to logos than is aisthesis, because it receives its impressions (typous) from there as well as from aisthesis. ${ }^{55}$

53. Proclus thinks there are three types of body which the soul animates, only the lowest of which is what we think of normally as the material body. Each soul has a first body, or vehicle (ochema), which is not temporally generated and which is indestructible, because each soul in virtue simply of its existence ensouls a body. Therefore, if souls are immortal, the primary body which they ensoul cannot be one which is generated and destroyed. Further, Proclus has reasons for thinking that some lower psychic functions survive the death of the material body, but are not attached to the highest body. Hence he posits a third body, between the two extremes, the pneumatic body, which survives the death of the material body but is itself eventually destroyed and re-generated. The acquisition of a lower body is described in a metaphorical sense as a putting on of a 'garment' (cbiton), and it is through these additions to the soul that the lower psychic functions come to be. See El. Th. props. 196, 205, 207-210, and esp. Dodd's note on prop. 209, p. 306-308. See also Opsomer 2006. Opsomer details the soul-powers which attach to (a) the aitherodes or angoeides ochema (aetherical or luminous body), (b) the pneumatic body, and (c) the hyliaion, ostreinon or ostreodes ochema (material, or oyster body). See p. 147 ff., and In Tim. III.237.2-6; III.298.23-27; and III.299.27-300.13, which he refers to.

54. In Remp. I.232.15-233.3.

55. In Remp. I.233.3-28. In his discussion in this text, Proclus considers the possibility that phantasia is double, with one part belonging to sensation and the other to memory. However, I think he decides that its ability to preserve impressions, as well as its ability to receive impressions from logos as well as aisthesis show that phantasia and aisthesis are different. Phantasia is related to and makes use of aisthesis, but they are not to be identified. Opsomer 2006, p. 143-144, interprets this passage slightly differently, concluding that there is a higher and a lower phantasia, a mnemoneutike and aisthetike sort respectively. The interpretation turns on whether the distinction between to mnemoneutikon and to aisthetikon at I.233.22-23 refers to a memorative part and a sensible part of phantasia, or whether to mnemoneutikon itself is phantasia, distinct from aisthesis. I think Proclus' point above (I.233.14-15), referring to the Philebus, that the painter in the soul belongs to the 
Why does Proclus still think that the soul has three parts, if he himself clearly states that there are two others besides the three in Plato's text? The answer comes in a brief comment at the end of his discussion of aisthesis and phantasia: "And enough about these parts, so we hold that, even if there should be other parts of the irrational soul, the present inquiry is about those parts which are useful with regard to political virtue, and about those being educated in this virtue." 56 Political virtue comes about because of the relation of ruling and being ruled, which has to do with appetites and the actions which issue from them. Although aisthesis and phantasia are related to appetites, they are not themselves appetitive, and so do not come under the study of political virtue. Hence there are only three parts of the soul, we now understand, in the sense that there are only three that are relevant to the investigation of political virtue and education found in the Republic.

4) Overall schema: In the final half page of this essay, Proclus quickly gives an overall scheme of how the parts of the soul are related to each other. ${ }^{57} \mathrm{He}$ says that the rational soul has both knowledge and appetite, and that each of these are themselves double, one branch tending upwards towards being or the immaterial, and the other downwards towards becoming. Moreover, the irrational powers of the soul are images of these four, so that there exist an upward and a downward moving cognition and appetite in the irrational soul:
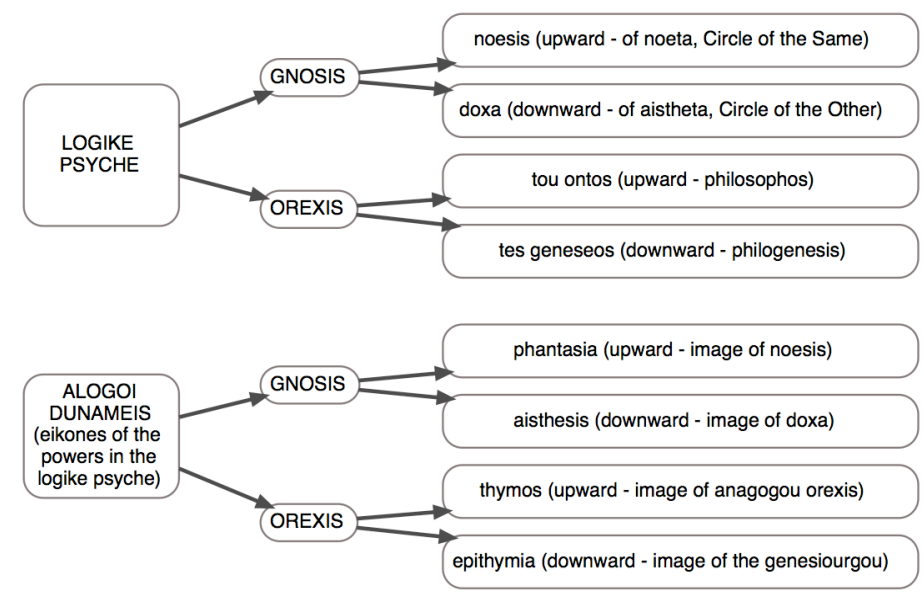

phantastikon and the scribe to koinen aisthesin, decides the point that this is the basic distinction.

56. In Remp. I.233.25-28.

57. In Remp. I.235.1-21. 
This scheme gives an account of why the various parts of the irrational soul exist, and why only thymos and epithymia are appetitive, and so relevant to political virtue. However, it raises a few questions as well, mainly having to do with the other schemata. With regard to the threequality theory, how should we characterise phantasia and aisthesis? ${ }^{58}$ They would both seem to be partless, have no appetite, and be intelligent. This would allow them to communicate with logos through two shared qualities, but not with anything else in the scheme. And if the three-quality scheme is meant to be a parallel to the three-quality theory of the elements, we should be surprised to find 'more' elements than the two extremes and the two means. ${ }^{59}$

With regard to the soul as an image of byparxis, dynamis, nous, how do the extra parts fit into the scheme? Both of these questions might be answered by saying that the earlier analyses are limited, because they focus only on the parts of the soul with appetite, or that are relevant to political virtue, and that this final scheme is a sort of widening of the view, to take in more of the complexity of Proclus' system. But in fact, even this scheme given in the final page doesn't capture all of the complexity in this essay itself, because at various places Proclus discusses how both thymos and epithymia have multiple desires. We will see that, while the complexity of thymos and epithymia might cause problems for the elegance of his various explanatory schemata, it will allow him to explain why political actions are many and various.

Finally, it is suprising to find only noesis and doxa as the knowing parts of the logike psyche. One would expect dianoia between them. ${ }^{60}$ This may perhaps be solved by saying that in this essay Proclus does not distinguish too clearly between the soul's discursive and non-discursive knowing powers, in order to remain close to the Platonic text. However, I think it points to another conclusion. Even the 'overall scheme' which we find here is a limited analysis. It gives the impression of being exhaustive, but actually leaves things out in order to fit the Republic text which is being examined.

58. The appetitive parts of the logike psyche here can be considered to supply the quality "appetitive" in the three-quality theory.

59. The three-quality theory is introduced, both with regard to the elements and with regard to the soul, in order to explain why two extremes with three qualities need to be joined by two mean terms. Note, however, that there are eight logically possible terms with one or the other of each of the three qualities.

60. Opsomer 2006, p. 144, in fact inserts dianoia into the scheme between noesis and doxa, referring to other texts. However, this does not solve the problem that this scheme is supposed to demonstrate how the irrational powers are images of and fall into the same divisions as the logike psyche. What irrational power would fall between phantasia and aisthesis as the image of dianoia? 
In fact, I think, all of Proclus' systematic taxonomies of the soul's parts are like this. They give the impression of being complete, but should be read as mutually complementary. In other words, no one analysis captures exhaustively all of the complexity of the soul, and our understanding of it comes rather from generating complementary discursive accounts taken from different perspectives. I think further that this sort of complementarity of accounts is derived from the inherent partiality of dianoia, in Proclus, and applies to his accounts of the other parts of his system. A discursive logos in Proclus is most often a divided image of a noetic reality, which points beyond itself to its noetic source. It in principle is not where thought must rest, but must point thought beyond discursivity.

Proclus is, paradoxically, an extremely systematic thinker, but one whose theory of philosophy precludes a completed discursive system, whether or not he himself realised this. If the Procline soul stops projecting its discursive logoi, it is not because it has reached some sort of dianoetic completion, but rather because it has either passed beyond dianoia to noesis, or given into the passivity of the body and started feeling instead of thinking. A soul which stays at the level of dianoia, but has no need to continue to generate accounts is an oxymoron in Procline terms.

I think this is why we have a diversity of analyses in Proclus, the most obvious being the difference between the Platonic and the Orphic/ Chaldaen set of terms. Moreover, we also have a diversity of philosophical styles, from the more geometrico style of the Elements of Theology, to the practice of philosophy through the etymology of divine names, in his commentary on the Cratylus, to the use of a succession of lemmata as leaping off points for the exposition of difficult questions in Platonic metaphysics, in commentaries like that on the Parmenides and the Timaeus, to an almost devotional style in his commentary on the Chaldean Oracles and his hymns. ${ }^{61}$

\section{V}

Socrates shows that the three parts of the soul differ by invoking the principle that the same thing can not undergo contraries. But what should we say, asks Proclus, about the love of pleasure and the love of money? Both belong to epithymia, yet they are often opposed to each other. Should not this opposition show that epithymia is in fact double, and so that there are four parts to the soul? ${ }^{62}$ Or if it does not, then the

61. See MacIsaac 2009.

62. Note that if there are more than three parts in the soul, according to Proclus, we will need more than the four cardinal virtues. See In Remp. I.228.28-229.9. 
other oppositions do not show that logos, thymos, and epithymia are essentially different (kat'ousian). Proclus' solution is to remind his reader that Socrates calls epithymia a beast with many heads. By this he means that epithymia is one, because it is thoroughly characterised by love of the body, and in this it differs from thymos and logos. But it is also many, precisely because of its association with the body. It is essentially one and many (ben te on kai polla kat'ousian). ${ }^{63}$ Basically, Proclus concedes the point that undergoing contraries shows that epithymia is not a simple ousia, while also asserting that it is exactly this multiplicity which stems from its love of the body which makes it one ousia. "This is why Plato did not say it was many beasts, but one beast with many heads, which lives at one time according to one and at another time according to another of its heads, but always in love with the body." 65 This is a nice solution.

He goes further in his analysis, and offers an ingenious explanation of why epithymia has these two main branches. Epithymia is a friend of the body and desires nothing but its preservation. But body as the object of appetite is double. Epithymia desires both the natural state of the body itself, and therefore is a lover of pleasure, and the necessary means of preserving this natural state, and therefore is a lover of riches. So insofar as both love of pleasure and love of riches have as their aim the preservation of the natural state of the body, they do not conflict, and Socrates is correct in saying that they stem from a single part of the soul. However, both of these desires tend to lose the natural state as their proper end. The first sort of desire, for the natural state of the body, tends instead to take as its end pleasure, which Proclus says accompanies or follows the path to the natural state. ${ }^{66}$ The second sort of desire, for the means to preserve the natural state, tends to take the means (riches) as an end in itself. And because both pleasure and riches are material (bylika) these desires fight each other. He means by this simply that the acquisition of pleasures requires one to spend money, and the miser accumulates by foregoing pleasures. ${ }^{67}$

According to the three-quality theory, we should expect epithymia to have parts. However, Proclus also states in this essay that thymos has two

63. In Remp. I.225.22-23.

64. In Remp. I.225.3-226.11.

65. In Remp. I..226.8-11.

66. In Remp. I.227.6-9: "Since one [appetite], instead of preserving the natural state [of the body] desires what accompanies the road to the natural state of the body it is in

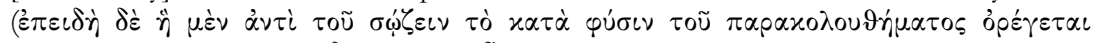

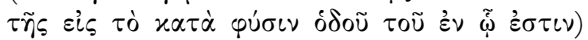

67. In Remp. I.226.22-227.27. 
branches, and for a reason similar to why epithymia is double. In explaining Socrates' comment that Justice in the soul puts into order the three parts of this soul "and any others there may be in between," states that thymos has two branches - love of honour (to philotimon), and the part which gets angry (to orgistikon) - just as epithymia is both love of riches and love of pleasure. ${ }^{69}$ What he means by this is clarified by an earlier discussion, in which Proclus asserts that the diversity of characters in nations is due to differences in which part of their souls is dominant, and is not due to differences in bodily temperaments (tais krasesin tou somatos). He does admit that in men without education (tois apaideutois) the soul puts forth differences in character because it follows, in a certain sense, bodily temperaments. But it is not all of thymos or epithymia which is affected in this way. It is not the love of honour or the love of riches, but the part of thymos which gets angry (to orgilon) and the love of pleasure which are affected by bodily temperaments. In the educated man not even these two branches of the irrational parts will be affected, or at least not very much. ${ }^{70}$

I am not quite sure what to say about this, because one would expect Proclus to say that thymos is also hen kai polla if it has these two branches. However, he does not really give an explanation of why thymos is partless according to the three-quality theory, even though it has these two branches, nor exactly how the part of thymos which gets angry is more allied to the body than the honour-loving part, which it is clear despises the body. $^{71}$ Perhaps he would argue that the love of honour and anger do not fall into conflict, as the love of money and love of pleasure do, and so thymos is more one than epithymia, despite its two branches. ${ }^{72}$ In all of this, as well, we must remember that the soul itself is one unified thing, and we are not speaking of 'parts' in the same exclusive manner as we would speak of the parts of bodies.

68. Resp. 443d.

69. In Remp. I.231.22-232.14.

70. In Remp. I.222.4-23.

71. In Remp. I.231.4-6. Perhaps the love of war and vengeance can be considered to involve one more in the body and its passions than the pure love of honour.

72. He does not in fact argue this, but it would seem to be the line he would have to take if it is the mutual conflict of love of pleasure and love of riches which shows epithymia to be hen kai polla. We can observe that the source of conflict between the two branches of epithymia is the materiality of their objects. In short, you must either save money or spend it, and if you save it you will not receive pleasures. We could imagine situations in which the love of honour and anger fall into conflict. However, as aiming at immaterial goods, it might be possible that Proclus doesn't see them as necessarily falling into conflict, as is the case with an epithymia which mistakes means for ends. However, I offer this only as a suggestion. 
In any case, we need to expand the schema by these two divisions:

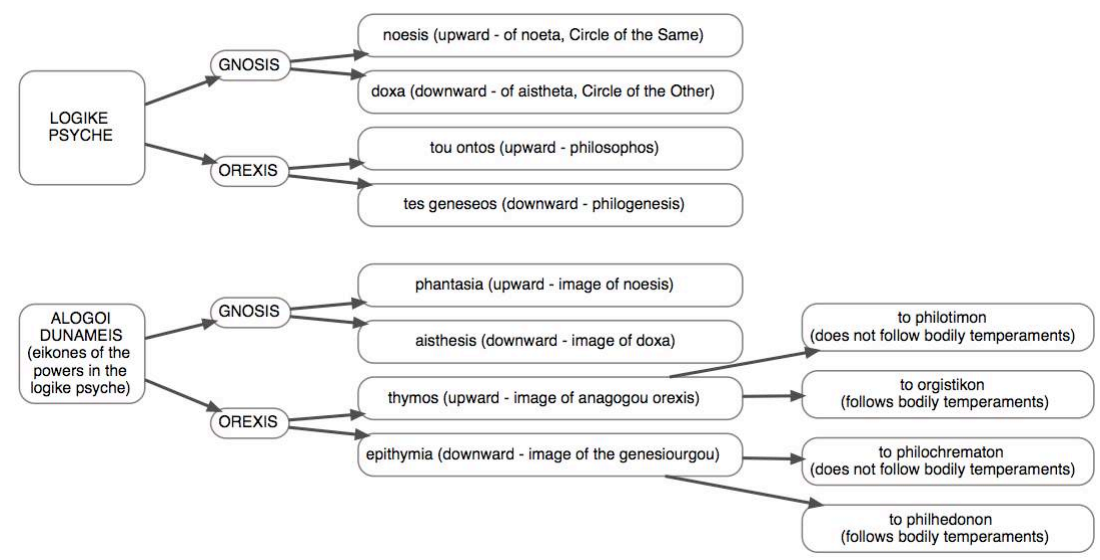

Near the end of his essay Proclus deals with the question of how the soul is one thing, even though it has all of these parts. He reports a challenge by the Stoic Medios, ${ }^{73}$ who divided the soul into eight parts. Asked by Longinus how his soul could still be one, Medios replied that Plato had the same problem with his tripartite soul. However, responds Proclus, Medios has his problem because he is a Stoic, and his divisions are therefore corporeal divisions. Plato, on the other hand, says that the soul is immaterial, and so does not have the same worry, because incorporeal things are united without confusion. ${ }^{74}$

Moreover, the soul is divided into logos and the irrational parts, with logos being more divine than the other parts, maintaining and ordering them. Proclus says their unity is analogous to that of form and matter, where it is the form which introduces unity. There is no need of a third term which unifies them. The soul's logos holds the place of form, and itself is able to unify the irrational life (ten alogon zoen) of the soul. ${ }^{75}$ Likely what Proclus means here over and above with the idea that the soul's ousia is hen kai polla, one and many, is that logos gives the soul as a whole unity, through the directives which come from its rule. In that sense, the just soul would be more one than the unjust.

73. See ref. in Festugière 1970, vol. 2, p. 38, note 5.

74. In Remp. I.233.29-234.17.

75. In Remp. I.234.21-25. 


\section{VII}

At this point it is obvious that this essay offers a fairly robust account of what one might call the 'political soul'. It is considerably more complex than the simple division into logos, thymos and epithymia found in the Republic, while at the same time remaining faithful to the Republic's schema through a sort of total deconstruction and reconstruction which we often find in Proclus. ${ }^{76}$ This account also shows that with a few nuances the political psychology of the Republic can do something we might really like it to do: give an account of the complexity of actual political behaviour.

As I mentioned above, Proclus thinks that the different characters of various national peoples have their source in differences in their souls. All human beings have the same psychic structure, but a person's overall character is determined by the part of the soul of which they make most use, and which consequently comes to be dominant in them. ${ }^{77}$ Hence the Greeks are pratically wise, the Thracians thymotic, and the Phoenicians are good at making money. ${ }^{78} \mathrm{I}$ am not suggesting that each nation only be classified in this simple manner, and Proclus' theory is not quite this simple.

The first thing to notice is that the idea of the dominance of one part of the soul or another is a necessary precision of the Republic's account. Without this precision, none of the inhabitants of the city in speech would actually be human, because each would possess only one third of a soul. A dominance of one part over the other, rather than the exclusive possession of one part, may be what the Socrates of the Republic actually meant, and the account of the degeneration of the city and the soul in books VIII and IX might indicate this. ${ }^{79}$ In any case, Proclus' account in which the soul is strongly one, but with parts which are more or less dominant allows for a more unified and fluid idea of character than the myth of the metals in the soul would suggest. ${ }^{80}$

76. What I mean by "total deconstruction and reconstruction" is the following. In essence, Proclus often begins with an account which he finds in Plato, carefully isolating each element. Then he discusses each element, in this case of the tripartite soul, making distinctions and additions in order to fit it into his much more complex metaphysics. An example is the two-fold distinction in Plato (Tim. 28a) between noesei meta logou and doxei met' aistheseos alogou which becomes in Proclus a fourfold distinction between noesis, logos, doxa, and aisthesis (In Tim. I.243.27-248.6). Finally he puts it all back together in such a way that the original account is preserved, but now forms the skeleton of his own much more robust and baroque theory.

77. In Remp. I.221.24-27.

78. In Remp. I.221.20-24.

79. See Resp. 550b.

80. Resp. 415a-c. 
Second, this idea of dominance also allows Proclus to talk about forms of life which are mixed. He does describe lives of logos, thymos, and epithymia, devoted exclusively to knowledge, honour, and pleasure. ${ }^{81}$ But he also describes lives which fall between these pure forms. As we have already seen, even the lives of thymos and epithymia allow the distinction between honour, anger (probably the martial life), riches, and pleasure. He goes further, however, and thinks Socrates alludes to lives which conform both to logos and thymos, or to thymos and epithymia, and that the lives which the soul lives are not unmixed. Men, for example, who pursue knowledge in order to be honoured for their learning, as well as men who pursue honour in order to be appreciated by men who have knowledge, would be living mixed lives of the first sort. On the other hand, both men who pursue riches in order to gain honour from men who admire the rich, and men who pursue honours in order to amass riches, would be living mixed lives of the second sort. It is interesting to note that Proclus does not include in his examples of mixed lives either of the lives which follow bodily temperaments, that of the angry man and of the pleasure-seeker, but they could probably be accomodated. The idea of mixed lives would likely allow Proclus to give an account of many of the various existing characters in terms of the basic parts of the Platonic political soul, and to do so within an account of political virtue and vice.

\section{VIII}

As I have said, Proclus' own exposition in this essay is rather brief, at times quite enigmatic, and a bit scattered in its order of exposition. However, if one looks at its contents in a more orderly manner than Proclus actually presents, as I have tried to do, we find the sort of engagement with politics which O'Meara details in Platonopolis. In this 7th essay of the In Rempublicam Proclus supplies in fact the elements of a quite robust Neoplatonic political philosophy.

In this short essay, Proclus gives an account of political virtue, by examining the parts of the soul insofar as it is master of the body and master of itself. The soul which has entered into relation with a terrestrial body possesses a mixture of psychic parts, which on their own would express an activity proper to immaterial mind on the one hand, and to irrational beasts on the other. But because these parts are together within a single life, they have relations of ruling and being ruled which are governed by the political virtues. As we have seen, these relations can be quite complex, and go some way towards explaining the complexity of actual political action. Proclus' theory would allow him to accept Plato's 
account of the varieties of good and bad men, and good and bad states, and in some ways give a more nuanced account of these.

Of course, the Neoplatonists did not consider political virtue to be the final word. The man who has mastered himself in his relation to body must begin to purify himself of all bodily interest, and begin in this life his ascent to the noetic and henadic union which is the true aim of the happy man. ${ }^{82}$

82. Baltzly 2004 discusses Julia Annas' point that the Platonic moral ideal of assimilation to god moves in two possibly contradictory directions. On the one hand, moral virtue requires an engagement in this world, while on the other, flight to the divine requires that we disengage from our bodily life. Baltzly argues that Proclus is less susceptible to this tension than Plotinus, because Proclus' rejection of Plotinus' doctrine of the undescended soul means that the human soul is more engaged in this world than it is for Plotinus. I think Baltzly is correct in pointing out that Proclus' adoption of the hierarchy of virtue, which includes the level of political virtue, means that there is such a thing for him as meaningful engagement with this world. However, I disagree with Baltzly's judgement of the degree to which Proclus thinks the soul is at home in the material world. Although its possession of the political virtues does imply that its presence in a material body is not a pure evil for the soul, and he says that its descent is due to its imitation of the providential activity of the gods (In Tim. III.5-24), Proclus also states clearly that life in the body is troublesome for souls (In Tim. III.25-13), and that it is not natural for them. Rather, a separate, imaterial, and incorporeal life is proper for the soul (In Alc. 256.11-14, In Remp. II. 349.20-26). So the other side of the tension also seems to be present. Part of Baltzly's argument rests on his interpretation of the well-known 'complete descent' of the Procline soul into genesis, with no part remaining above (El.Th. prop. 211). This seems to imply, as Baltzly says, that "We can come to know the various levels within Intellect and the henads only by means of their logoi or images within our souls... The perfection of our natures which is effected through becoming virtuous is a perfection of an essentially psychic nature. Proclus should therefore reject the view that the civic virtues are ever left behind" (p. 308-309). Baltzly is correct in thinking that the defining characteristic of the Procline soul is its knowledge of all things through its own discursive projection of logoi; see MacIsaac 2001. However, this discursive activity is related in complex ways to other, non-discursive or not-completely discursive elements and activities within the soul. This relation is indicated by passages on the soul's noesis (In Tim. I.247.10-25) and on its byparxis (Plat. Theol. I.3.15.1-16.1 Saffrey-Westerink), as well as his use of the terms the "flower of nous" (anthos nou) (Phil. Chald. 210.29 Des Places), the "flower of the soul" (anthos tes psyches) (In Parm. 1071. 30), the "one of the soul" (ben tes psyches) (In Parm. 1071.26), the "most unified part of the soul" (henoeidestaton tes psyches) (Phil. Chald. 210.30 Des Places), and the "highest part of the soul" (akrotaton tes psyches) (In Tim. II.203.31), and by such descriptions as at In Crat. 34.4-5, of associating our own noesis with the divine light. To my knowledge, no one has explained satisfactorily the relation between the discursive and non-discursive knowing activities of the Procline soul, especially with regard to his statement in the Elements that no part remains above when it descends into genesis. Put simply, if no part remains above, what status does the soul's ousia, its noesis, or its 'one' or 'flower' have in the completely descended soul? For a discussion which touches on this, see Steel 1978, p. 46-47, 69-73. See also Mazilu 2008, p. 71-83. For the fullest discussion, see Gritti 2008, p. 75-77, 109-120. Gritti's account is very good, but I do not agree with 


\section{BIBLIOGRAPHY}

Aвbаte, M. 1999: "Gli aspetti etico-politici della Repubblica nel commento di Proclo (Dissertazioni VII/VIII e XI)", in M. Vegetti \& M. Abbate 1999, p. 207-218.

- 2004 : Proclo, Commento alla Repubblica di Platone (Dissertazioni 1, 3-5, 7-12, 14-15, 17), saggio introduttivo, traduzione e commento di —, Milan, 2004 (Bompiani Il pensiero occidentale).

— 2006: "Metaphysics and Theology as Methodological and Conceptual Paradigms in Proclus' Ethico-Political Theory" in M. Perkams \& R.M. Piccione 2006, p. 186200.

BALtzly, D.Ch. 2004 : “The virtues and 'becoming like god': Alcinous to Proclus", Oxford Studies in Ancient Pbilosophy, 26 (2004), p. 297-321.

- 2008: "Pathways to Purification : the Cathartic Virtues in the Neoplatonic Commentary Tradition", in H. Tarrant \& D.Ch. Baltzly (éd.), Reading Plato in Antiquity, Londres, 2006, p. 169-184.

BrisSON, L. 2004: "La doctrine des degrés de vertus chez les néo-platoniciens : une analyse de la Sentence 32 de Porphyre, de ses antécédents et de ses conséquences", Les Études platoniciennes, 1 (2004), p. 271-286.

Cardullo, L. 1985 : Il linguaggio del simbolo in Proclo: analisi filosofico-semantica dei termini symbolon/eikôn/synthêma nel Commentario alla Repubblica, Catania, 1985 (Symbolon, 4).

Cheneval, F. 1996 : "Proclus politisé : la réception politique de Proclus au Moyen Âge tardif", Archiv für Geschichte der Philosophie, 78 (1996), p. 11-26.

DES PLACES, É. 1971: Oracles chaldaïques : avec un choix de commentaires anciens, texte établi et traduit par — Paris, 1971 (Collection des Universités de France).

Dillon, J. 2001 : “The Neoplatonic Reception of Plato's Laws", in F.L. Lisi (ed.), Plato's Laws and its Historical Significance: Selected Papers of the I International Congress on Ancient Thought, Salamanca, 1998, Sankt Augustin, 2001, p. 243-254.

DodDs, E.R. 1963: Proclus, The Elements of Theology, A Revised Text with Translation, Introduction and Commentary by -, Londres, 21963.

FestugiÈre, A.-J. 1969 : "L'ordre de lecture des dialogues de Platon aux Ve-VIe siècles", Museum Helveticum, 26 (1969), p. 281-296.

— 1970 : Proclus, Commentaire sur la République, traduction et notes par —, Paris, 1970, 3 vol. (Bibliothèque des textes philosophiques).

Gerson, L. 2004 : “The Neoplatonic interpretation of Platonic ethics", in M. Migliori \& L.M. Napolitano Valditara (ed.), Plato Ethicus: Philosophy is Life: Proceedings of the International Colloquium, Piacenza (Italy), 2003, Sankt Augustin, 2004 (Lecturae Platonis, 4), p. 151-164 (= Plato Ethicus : La filosofia è vita, Brescia, 2008 [Filosofia, Nuova Serie, 51. Lecturae Platonis, vol. 3], p. 161-175).

GritTi, E. 2008 : Proclo : dialettica, anima, esegesi, Milan, 2008 (Il filarete. Università degli studi di Milano, Facoltà di lettere e filosofia. Sezione di filosofia, 257).

Hankey, W.J. 2003 : "Political, Psychic, Intellectual, Daimonic, Hierarchical, Cosmic, and Divine: Justice in Aquinas, Al-Fârâbî, Dionysius, and Porphyry", Dionysius, 21 (2003), p. 197-218.

Kuisma, O. 1996 : Proclus' defence of Homer, Helsinki, 1996 (Commentationes humanarum litterarum, 109).

her judgement that Proclus' account of a psychic noesis and its relation to the soul's dianoia is unsuccessful. See MacIsaac forthcoming. 
LONGO, A. 2002: "Gli argomenti di Teodoro di Asine sull'educazione comune di uomini e donne nel Commento alla Repubblica di Proclo (I 253-5 Kroll)», Elenchos, 23.1 (2002), p. 51-73.

MacIsaAc, D.G. 2001: The Soul and discursive reason in the Philosophy of Proclus (Ph.D. Thesis, U. Notre Dame IN, 2001, unpublished).

- 2009: "Platonic Deconstruction: A review-article of Neoplatonism after Derrida. Parallelograms. By Stephen Gersh", Dionysius, 17 (2009, forthcoming).

— forthcoming: "Nónoıs, dialectique et mathématiques dans le Commentaire de Proclus aux Éléments d'Euclide," in A. Lernould (ed.), Études sur l'In Euclidem de Proclus, Villeneuve d'Ascq.

Mazilu, D. 2008 : Raison et mystique dans le néoplatonisme, Bucarest, 2008 (Zeta series in neoplatonism, 1).

NArbonne, J.-M. 2004 : “De l'Un matière à l'Un forme: la réponse de Proclus à la critique aristotélicienne de l'unité du politique dans la République de Platon (In Remp. II, 361-368)", in J.-M. Narbonne \& A. Reckermann (ed.), Pensées de l'«Un» dans l'bistoire de la philosophie : études en hommage au professeur Werner Beierwaltes, ParisSaint Nicolas (Québec), 2004 (Zêtêsis), p. 3-25.

O’MEARA, D.J. 1992: "Vie politique et divinisation dans la philosophie néoplatonicienne", in M.-O. Goulet-Cazé, G. Madec \& D. O’Brien (ed.), $\Sigma O \Phi I H \Sigma$ MAIHTOPE $\boldsymbol{\Sigma}=$ "Chercheurs de Sagesse»: Hommage à Jean Pépin, Paris, 1992 (Collection des Études Augustiniennes. Série Antiquité, 131), p. 501-510.

- 1999: "Plato's Republic in the school of Iamblichus", dans M. Vegetti \& M. Abbate 1999, p. 193-205.

- 2002: "Neoplatonic Cosmopolitanism : Some Preliminary Notes", in M. Barbanti,

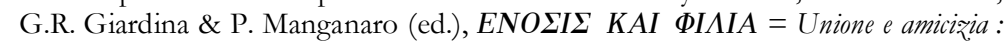
omaggio a Francesco Romano, Catania, 2002), p. 311-315.

- 2003 : Platonopolis, Oxford, 2003.

Opsomer, J. 2006 : “Was sind irrationale Seelen ?”, in M. Perkams \& R.M. Piccione 2006, p. 136-166.

Perkams, M. 2006 : “An Innovation by Proclus : the Theory of the Substantial Diversity of the Human Soul", in M. Perkams \& R.M. Piccione 2006, p. 167-185.

Perkams, M. \& R.M. Piccione 2006 : Proklos : Methode, Seelenlebre, Metaphysik: Akten der Konferenz in Jena am 18.-20. September 2003, herausgegeben von —, Leiden, 2006 (Philosophia antiqua, 98).

PICHLER, R. 2006 : Allegorese und Ethik bei Proklos : Untersucbungen zum Kommentar zu Platons Politeia, Berlin, 2006 (Klassische Philologie, 2).

Polychronopoulou, K. \& C. Terezis 2004: “The Neoplatonic Approach of Proclus to Music in Relation to Politics and Metaphysics", dans L. Cheney \& J. Hendrix (ed.), Neoplatonic Aesthetics: Music, Literature and the Visual Arts, New York, [...], 2004, p. 37-44.

SAFFrey, H.-D. \& L.G. WeSterink 1968-1997: Proclus, Théologie platonicienne, texte établi et traduit par —, Paris, 6 vol., 1968-1997 (Collection des Universités de France).

SAfFrey, H.-D. \& A.-Ph. Segonds 2001 : Marinus, Proclus ou Sur le bonheur, texte établi et traduit par —, Paris, 2001 (Collection des Universités de France).

Sheppard, A.D.R. 1980 : Studies on the 5th and 6th Essays of Proclus' Commentary on the Republic, Göttingen, 1980 (Hypomnemata, 61).

Stalley, R.F. 1995: "The Unity of the State: Plato, Aristotle and Proclus", Polis, 14 (1995), p. 129-149.

— "Plato and Aristotle on political unity", in M. Vegetti \& M. Abbate (ed.), La Repubblica di Platone nella tradizione antica, Naples, 1999 (Saggi Bibliopolis, 60), p. 29-48. 
STEEL, C. 1978: The Changing Self: a Study on the Soul in Later Neoplatonism : Iamblichus, Damascius and Priscianus, Bruxelles, 1978 (Verhandelingen van de Koninklijke academie voor wetenschappen, letteren en schone kunsten van België. Klassen der letteren, 85).

Vegetti, M. \& M. AbBate 1999 : La Repubblica di Platone nella tradirione antica, a cura di —, Naples, 1999 (Saggi Bibliopolis, 60). 